\title{
Revisiting Domestic Savings and Economic Growth Analysis in Ghana
}

\author{
Anthony Siaw ${ }^{1}$, Koduah Dawud Enning², Robert Becker Pickson ${ }^{1}$ \\ ${ }^{1}$ College of Economics and Management, Sichuan Agricultural University, Chengdu, China \\ ${ }^{2}$ Research, Monitoring and Evaluation Department, Ghana Cocoa Board, Accra, Ghana \\ Email: myselfpickson@yahoo.com
}

How to cite this paper: Siaw, A., Enning, K.D. and Pickson, R.B. (2017) Revisiting Domestic Savings and Economic Growth Analysis in Ghana. Theoretical Economics Letters, 7, 1382-1397. https://doi.org/10.4236/tel.2017.75093

Received: July 3, 2017

Accepted: August 8, 2017

Published: August 11, 2017

Copyright (c) 2017 by authors and Scientific Research Publishing Inc. This work is licensed under the Creative Commons Attribution International License (CC BY 4.0).

http://creativecommons.org/licenses/by/4.0/

cc) (i) Open Access

\begin{abstract}
This study set out to ascertain the relationship between domestic savings and economic growth in the midst of antecedent variables with yearly data during the period of 1970-2013. Using Johansen cointegration test and vector error correction model, the study found that, in the long-run, consumer price index, trade openness, foreign direct investment, and domestic savings have positive significant impacts on economic growth. With respect to the shortrun estimates, the lags in domestic savings have negative but insignificant effects on economic growth. It is, therefore, incumbent on the government to uphold, guard, and sustain the political stability so jealously since it can create a conducive financial atmosphere necessary to mobilise savings in order to improve the growth rate of the Ghanaian economy. It is also recommended that the central bank pays a particular attention to rural savings mobilisation through the regulation of mobile banking by allowing the telecommunication companies to also pay interest to savers on their mobile deposits and establishment of banking financial institutions at least in each district in Ghana.
\end{abstract}

\section{Keywords}

Domestic Savings, Economic Growth, Consumer Price Index, Trade Openness, Foreign Direct Investment

\section{Introduction}

The relationship between savings and economic growth is still an open debatable issue to academicians and policy makers. According to Solow [1], savings influence the growth rate of an economy because higher savings result in higher capital accumulation which in turn improves the rate of economic growth. This presupposes that increased savings contribute directly to economic growth, and as such, it has resulted in strong macroeconomic policy recommendations for 
growth and development in numerous countries. One of the fundamental objectives of macroeconomic policies is to attain sustainable economic growth. Accordingly, the linkages between economic growth and other macroeconomic factors are very significant in determining the policies which steer economic growth. Deaton [2] contended that causation is imperative not just for the understanding the process, but for the design of the policy. He buttressed that notion that saving is an important determinant of economic growth as well as economic stability.

Theoretically, the studies on the association between economic growth and saving were dated from the Harrod [3] and Domar [4] growth model which opined that economic growth hinges on the level of savings, and as a result, an increase in savings leads to a surge in the rate of economic growth. However, in the neoclassical growth model led by Solow [1] and Swan [5], changes in savings impact economic growth until the steady state output only in the short-run. Also, in accordance with the endogenous growth theory, Romer [6], Lucas [7], and Rebelo [8] indicated that a rise in savings can trigger a permanent increase in economic growth.

Although economic theories postulate that savings are one of the main factors influencing economic growth, empirical studies on the nexus between savings and economic growth have attained mixed conclusions. Carroll-Weil hypothesis (Carroll and Weil, [9]) avows that it is economic growth that contributes to savings, not savings to growth. Some empirical studies conducted by Jappelli and Pagano [10], Sinha and Sinha [11], Rodrik [12], Agrawal [13], Carroll et al. [14], Anoruo and Ahmad [15], Verma [16], and Abu [17] all found results similar to Carroll and Weil [9]. Conversely, other empirical studies like Lewis [18], Levine and Renelt [19], Mankiw et al. [20], Alguacil et al. [21], and Sajid and Sarfraz [22] favoured the capital fundamentalists who believe that savings cause economic growth. Shahbaz and Khan [23], empirically threw their weight behind capital fundamentalists by suggesting that the direction of causality runs from savings to economic growth. They stated that capital accumulation through savings will translate positively into investment, and hence, sustainable economic growth in the long run. This presupposition was, however, contested by Ogoe [24], and Pickson et al. [25] who explicitly showed no evidence of the existence of a long-term relationship between savings and economic growth.

In point of fact, empirical studies on the relationship between savings and economic growth in Ghana are limited and not expansive. Ogoe [24] and Pickson et al. [25] commonly paid attention to the degree of responsiveness of economic growth to changes in gross domestic savings by testing for bivariate cointegration and Granger causality between savings and economic growth. The authors found no evidence of the existence of a long-run equilibrium relationship, but exhibited bi-directional and unidirectional causality relationship between domestic savings and economic growth in the short-run respectively. These studies did not really focus on how the falling savings rate and other growth driven variables impact on economic growth in Ghana bearing in mind the significant 
role played by savings and other growth driven variables in economic growth and development of a nation. This study, therefore, differs from other studies in the literature primarily in involving antecedent variables like consumer price index, trade openness, and foreign direct investment to ascertain whether the long-run or short-run relationship between savings and economic growth would change by employing Johansen cointegration test and vector error correction model.

In view of that, this paper is structured as follows; the section two considers the review of related literature, the econometric methodology is presented in section three, section four is concerned with the empirical results and analyses, whilst the section five focuses on the conclusion and policy implications.

\section{Literature Review}

The question of whether or not economic growth hinges on the level of savings has dominated theoretical and empirical debate for a long time. The proponents for this presumption believe that savings influence the growth rate of an economy since higher savings result in higher capital accumulation which in turn enhances the rate of economic growth (Harrod, [3]; Domar, [4]; Lewis, [18]; Solow, [1]; Romer, [6]; Lucas, [7]; Rebelo, [8]; Levine and Renelt, [19]; Mankiw et al., [20]; and Deaton, [2]). Also, Alguacil et al. [21], Sajid and Sarfraz [22], and Shahbaz and Khan [23] have argued that an increase in savings can trigger improvement in the growth rate of an economy. However, Carroll-Weil hypothesis (Carroll and Weil, [9]) avows that it is economic growth that contributes to savings, not savings to growth. Other relevant empirical literature such as Jappelli and Pagano (1994 [10]), Sinha and Sinha [11], Rodrik [12], Agrawal [13], Carroll et al. [14], Anoruo and Ahmad [15], Verma [16], and Abu [17] have reported that economic growth can tremendously contribute to savings.

In relation to Misztal [26], Ijeoma et al. [27], and Sothan [28], savings and economic growth are independent of each other. Moreso, Ogoe [24], and Pickson et al. [25] found no long-run relationship between savings and economic growth, whilst other empirical studies, for instance, Anoruo and Ahmad [15], Shahbaz and Khan [23], Abu [17], and El-Seoud [29] all have established longrun association between savings and economic growth. Although the relationship between savings and economic growth has been extensively discussed and examined in economic literature, different countries also have different effects of savings; hence reached inconclusive findings.

Verma [16] used Autoregressive Distributed Lag (ARDL) Bounds testing technique to analyse the long-run relationship between gross domestic savings, gross domestic investment and economic growth in India with data for the period 1951-2004. The results revealed that gross domestic savings, gross domestic investment, and economic growth have long-run relationship, with the exception of when economic growth was the dependent variable. The study also indicated that savings do not contribute to growth, but growth leads to savings, savings drive investment both in the short-run and in long-run and that investment is the driver of economic growth in India during the period. 
Sajid and Sarfraz [22] in their study titled "the effect of savings on economic growth in Pakistan", employed Johansen cointegration test and vector error correction model (VECM) to analyse yearly data between the periods of 19732003. The study found that there is a bi-directional causality between savings and economic growth in the long run. However, the short-run results showed that there exists a unidirectional causality running from economic growth to domestic savings. Generally, the short run results supported the Keynesian's view that savings hinge on the level of output.

In a simultaneous equation framework using two-stage least squares with panel data covering the period of 1989-2003, Chaturvedi et al. [30] investigated the interaction between economic growth, saving rate and inflation for SouthEast and South Asian economies. The authors found that there exists a bi-directional and positive relationship between saving rate and growth. Inflation has a highly significant negative effect on growth but positive effect on saving rate. Inflation is not affected by growth but is largely determined by its past values, and saving rate is not affected by interest rate. It was, therefore, concluded that these findings for countries in Asia with widely divergent values of aggregates are very relevant for development policies and strategies.

Mehrara and Musai [31] deployed Autoregressive Distributed Lag (ARDL) to analyse the relationship between savings and economic growth in Iran during the period of 1970 to 2010 . The study established that there exists a long-run relationship among economic growth, gross domestic savings, labour force, oil revenue, and education. It was discovered that gross domestic savings relate positively to economic growth in both long-run and short-run. However, based on the weak influence of savings on economic growth, the study suggested to government and policy makers to put in place policies that would enhance productivity and human capital in order to accelerate economic growth in Iran.

The controversy surrounding the direction of causality between savings and economic growth also prompted Mehta and Rami [32] to examine empirically the causal relationship between savings and economic growth in India covering the period of 1951 to 2011. The study indicated that there is no evidence of dependence between savings and economic growth. The findings contradicted the Solow's hypothesis that higher savings lead to economic growth and Keynesian's assertion that saving is a function of income levels. The researchers, therefore, reached the notion that interaction between economic growth and savings which exists, in theory, does not exist in practice.

Najarzadeh et al. [33] in their study titled "Relationship between Savings and Economic Growth in Iran" used Autogressive Distributive Lag (ARDL) model to examine the relationship between savings and total and non-oil economic growth over period of 1972-2010. Results from the study indicated that savings has significant positive effect on total and non-oil economic growth. The study again demonstrated that both types of economic growth have positive and significant influence on savings. Also, using Error Correction Model (ECM) and Wald Test, it was established that there is a long-run bi-directional causality 
between savings and economic growth, and savings and non-oil economic growth.

Er et al. [34] utilised Autogressive Distributed Lag (ARDL) to analyse the link between saving, inflation, and economic growth in Turkey for the period 2003Q1 to 2012Q2. The study found that, in the long-run, inflation and economic growth relate positively to savings in the Turkish economy. Nevertheless, no significant relationship found between interest rates and savings in the long-run as well as inflation and savings in the short-run. The study further indicated that economic growth has the most explanatory power on savings in the Turkish economy.

In Cambodia, Sothan [28] attempted to determine the direction of causality gross domestic savings and economic growth during the period of 1989-2012. It was found that there is no causality running from domestic savings to economic growth. Likewise, economic growth was also not found to Granger cause domestic savings. The study, therefore, concluded that domestic savings and economic growth are independent of each other in Cambodia.

Jagadeesh [35] applied Autoregressive Distributive Lag (ARDL) model coupled with Dynamic Ordinary Least Squares (DOLS) approach to empirically investigate the impact of savings on economic growth in Botswana. Using annual time series data for the period of 1980 to 2013, it was found that there existed a long run relationship between gross domestic savings, gross capital formation, inflation, export, labour force, and economic growth. The study indicated that gross domestic savings, inflation, and export are the significant determinants of economic growth in Botswana.

Pickson et al. [25] deployed Johansen Cointegration test coupled with Vector Autoregression and Granger Causality test to examine the relationship between gross domestic savings and economic growth in Ghana over the period of 19722013. The study exhibited no long-run relationship between gross domestic savings and economic growth, but found that, there is a unidirectional line of causation running from gross domestic savings to economic growth in Ghana. Since deposit rate is the opportunity cost of money demand for other purposes, the authors suggested to the Bank of Ghana to use the monetary policy instruments to influence and advise the commercial banks to peg the deposit rate relatively higher at least equal or little above the existing interest rate.

In the nutshell, it is evident that most of the empirical literature focused on the degree of responsiveness of economic growth to changes in gross domestic savings by testing for bivariate cointegration and Granger causality between savings and economic growth. This current literature, therefore, uses Johansen cointegration test and vector error correction model to analyse how the falling savings rate and other growth driven variables impact on economic growth in Ghana bearing in mind the significant role played by savings and other growth driven variables in economic growth and development of a nation.

\section{Econometric Methodology}

\subsection{Data Source}

The study used annual time series data spanning during the period of 1970- 
2013. Data on gross domestic savings, gross domestic product, consumer price index, trade openness, and foreign direct investment were extracted from the World Development Indicators [36].

\subsection{Model Specification}

This study specified multiple linear regression model which according to Onwumere [37] involves more than a single independent variable. The equation for multiple linear regression is given in the following form:

$$
\mathrm{GDP}_{t}=\beta_{0}+\beta_{1} \mathrm{GDS}_{t}+\beta_{2} \mathrm{CPI}_{t}+\beta_{3} \mathrm{TO}_{t}+\beta_{4} \mathrm{FDI}_{t}+\varepsilon_{t}
$$

In view of a log-linear model, the Equation (1) is expressed as follows:

$$
\ln \mathrm{GDP}_{t}=\beta_{0}+\beta_{1} \ln \mathrm{GDS}_{t}+\beta_{2} \ln \mathrm{CPI}_{t}+\beta_{3} \ln \mathrm{TO}_{t}+\beta_{4} \mathrm{FDI}_{t}+\varepsilon_{t}
$$

where $\mathrm{GDP}_{t}$ indicates gross domestic product, $\mathrm{GDS}_{t}$ denotes gross domestic savings, $\mathrm{CPI}_{t}$ represents consumer price index as a proxied for macroeconomic instability, $\mathrm{TO}_{t}$ is the trade openness, $\mathrm{FDI}_{t}$ indicates foreign direct investment, $\ln$ represents natural logarithm and $\varepsilon_{t}$ indicates the error term.

It is imperative to note that transforming Equation (1) into natural logarithm as given in Equation (2) assists to compute the variables in the same form and make the interpretation of the results better and easy as well as reduce heteroscedasticity.

Table 1 presents the expected signs of the independent variables.

\subsection{Analytical Techniques}

Dickey-Fuller Generalised Least Squares and Phillips-Perron tests were used to validate the stationarity of the variables concerned in order to avoid the problem of non-stationarity with time series data. Further, the long run equilibrium relationship of Equation (2) was examined using Johansen cointegration test. In an attempt to establish the relationship between the variables, the study employed vector error correction model (VECM) which had been used in literature to estimate the short and long dynamics of variables concerned. Eventually, the error correction model (ECM) assisted in estimating the short run dynamic parameters. Specifically, the ECM helps in ascertaining the speed of adjustment to the equilibrium.

Table 1. Expected signs of the independent variables.

\begin{tabular}{ccc}
\hline Variables & Theoretical/Empirical Basis & $\begin{array}{c}\text { Expected } \\
\text { Signs }\end{array}$ \\
Gross Domestic Savings & $\begin{array}{c}\text { Romer [6], Aghion et al. [38], } \\
\text { Sajid and Sarfraz [22] }\end{array}$ & Positive \\
Consumer Price Index & Mundell [39] & Negative \\
Trade Openness & Capolupo and Celi [40] & Inclusive \\
Foreign Direct Investment & Xu and Wang [41], Gursoy et al. [42] & Positive \\
\hline
\end{tabular}




\section{Empirical Results and Analyses}

\subsection{Results from Stationarity Test}

The study employed Dickey-Fuller Generalised Least Squares and Phillips-Perron tests to validate the stationarity of the variables concerned. The results from the unit root tests are presented in Table 2.

The Dickey-Fuller Generalised Least Squares (DF-GLS) test results showed that gross domestic product, gross domestic savings, consumer price index, trade openness, and foreign direct investment were non-stationary at their levels when trended and not trended. These results were confirmed by the PhillipsPerron (PP) test results. The study then proceeded to the first difference and found all the variables to be stationary at their first difference when trended and not trended as indicated by both DF-GLS and PP test results.

\subsection{Cointegration Test}

The Johansen cointegration test was employed to assess the long-run relationship between economic growth and its regressors. The results of Johansen cointegration test are presented in Table 3.

The results of trace and the maximum-Eigen tests are reported in the upper and second segments of Table 3 respectively. The trace statistics test confirmed the existence of at least two (2) cointegrating equations among the variables at 5\% significant level. However, maximum-Eigen statistics indicated that there exists one (1) cointegrating equation among the variables at 5\% significant level.

Table 2. Results from the unit root tests.

\begin{tabular}{|c|c|c|c|c|c|}
\hline \multirow{3}{*}{ Variables } & \multicolumn{2}{|c|}{ DF-GLS Test } & \multicolumn{2}{|c|}{ Phillips-Perron Test } & \multirow{3}{*}{ IO } \\
\hline & \multicolumn{2}{|c|}{ Level } & \multicolumn{2}{|c|}{ Level } & \\
\hline & No Trend & Trend & No Trend & Trend & \\
\hline $\operatorname{lnGDP}$ & 0.828 & -0.633 & 3.681 & -0.396 & \\
\hline $\operatorname{lnGDS}$ & 2.001 & -2.865 & 0.360 & -4.596 & \\
\hline $\operatorname{lnCPI}$ & 0.437 & -0.633 & -2.367 & -0.148 & \\
\hline $\ln \mathrm{TO}$ & -1.444 & -1.987 & -1.138 & -2.265 & \\
\hline FDI & -1.626 & -2.141 & -1.069 & -0.259 & \\
\hline \multirow{3}{*}{ Variables } & \multicolumn{2}{|c|}{ DF-GLS Test } & \multicolumn{2}{|c|}{ Phillips-Perron Test } & \\
\hline & \multicolumn{2}{|c|}{ First Difference } & \multicolumn{2}{|c|}{ First Difference } & IO \\
\hline & No Trend & Trend & No Trend & Trend & \\
\hline$\Delta \operatorname{lnGDP}$ & $-2.561^{\star *}$ & $-3.310^{* *}$ & $-4.127^{\star * *}$ & $-5.884^{* * *}$ & $I(1)$ \\
\hline$\Delta \operatorname{lnGDS}$ & $-3.926^{\star * *}$ & $-5.112^{\star * \star}$ & $-10.677^{\star * \star}$ & $-10.715^{\star * *}$ & $I(1)$ \\
\hline$\Delta \operatorname{lnCPI}$ & $-2.338^{*}$ & $-2.739^{*}$ & $-3.915^{* * *}$ & $-4.802^{* * *}$ & $I(1)$ \\
\hline$\Delta \operatorname{lnTO}$ & $-3.594^{* * *}$ & $-4.264^{\star * *}$ & $-4.278^{* * *}$ & $-4.193^{* *}$ & $I(1)$ \\
\hline$\Delta \mathrm{FDI}$ & $-2.487^{\star \star}$ & $-3.001^{\star}$ & $-6.798^{* * *}$ & $-7.523^{\star * *}$ & $I(1)$ \\
\hline
\end{tabular}

Note: ${ }^{* *},{ }^{* *}$ denote rejection of null hypothesis of $1 \%$ and $5 \%$ significance levels respectively. $\Delta$ is the first difference operator. 
Table 3. Johansen test results for cointegration.

\begin{tabular}{ccc}
\hline \multicolumn{3}{c}{ Unrestricted Cointegration Rank Test (Trace) } \\
\hline Hypothesized No. of CE(s) & Trace Statistics & 0.05 Critical Value (Trace) \\
\hline None $^{*}$ & 82.28517 & 69.81889 \\
At most $1^{*}$ & 48.28682 & 47.85613 \\
At most 2 & 27.38374 & 29.79707 \\
At most 3 & 12.17404 & 15.49471 \\
At most 4 & 0.514483 & 3.841466 \\
\hline Unrestricted Cointegration Rank Test (Maximum-Eigenvalue) \\
\hline Hypothesized No. of CE(s) & Maximum-Eigenvalue & 0.05 Critical Value (Max) \\
\hline None* & 33.87587 & 33.87587 \\
At most 1 & 20.90308 & 27.58434 \\
At most 2 & 15.20908 & 21.13162 \\
At most 3 & 11.65956 & 14.26460 \\
At most 4 & 0.514483 & 3.841466
\end{tabular}

Note: Trace indicates no cointegration at the 0.05 level. Maximum-Eigenvalue indicates no cointegration at the 0.05 level.

Since, trace statistics test is robust to skewness and excess kurtosis, and can also be adjusted for the degree of freedom; this study, therefore, used the trace statistics and suggested that there exists a long-run relationship between consumer price index, trade openness and foreign direct investment, gross domestic savings, and economic growth.

\subsection{VECM Long-Run Estimation Results}

The long run equation for the economic growth model was estimated using the VECM and the results are shown in Table 4.

As indicated in Table 4, the coefficient of gross domestic savings is 0.437489 and statistically significant at $1 \%$ level. This implies that in the long run, an increase in gross domestic savings contributes positively in realization of economic growth. This maybe so, as the estimated result indicates long term postponement of the present consumption into the future, which means capital accumulation for meaningful investment leading to a rise in economic growth. This confirms the validity of the Solow [1] growth model in Ghana. The result also concurs with empirical studies by Aghion et al. [38], Tang and Tan [43], and Jagadeesh [35], but opposes Nwanne [44] who suggested that domestic savings have a negative and significant impact on economic growth in Nigeria.

The elasticity of the consumer price index has a positive sign of 0.062524 and it is significant at $1 \%$ level of significance. This means that a proportionate increase in the general price level will grow the economy less than proportionately in the long run. This is due to the fact that an increase in general price level reduces real money balance and worth of people. Individuals then diversify their 
Table 4. VECM long-run estimation results.

\begin{tabular}{cccc}
\hline \multicolumn{4}{c}{ Dependable Variable: lnGDP } \\
\hline Regressors & Coefficient & Standard Error & t-Statistic \\
\hline $\ln$ GDS & 0.437489 & 0.07165 & $6.10591^{* * *}$ \\
$\ln$ CPI & 0.062524 & $43 \mathrm{E}-05$ & $5.93076^{* * *}$ \\
$\ln$ TO & 0.286961 & 0.05241 & $5.47491^{* * *}$ \\
FDI & 0.000254 & 0.00883 & $7.07896^{* * *}$ \\
C & -23.19912 & & \\
\hline
\end{tabular}

Note: ${ }^{* *}$ denotes significance at $1 \%$ level.

portfolio to other interest bearing assets. This phenomenon drives down interest rate and propels greater capital accumulation to spark a faster output growth. Again, a mild inflation rate of $6 \%$ faster than the cost of production encourages large scale production and hence economic growth, since high prices correlate with high profit margins. Because entrepreneurs' profit margins are subjected to tax, government tax revenue also increases to finance growth related projects. The finding confirms the studies conducted by Oleka et al. [45], Mbulawa [46], and Jagadeesh [35].

As evident from the results, the degree of trade liberalisation which is proxied by trade openness has a positive and statistically significant effect on economic growth in Ghana. The positive coefficient implies that a proportionate allowance of trade liberalisation uplifts the economic fortunes by $0.29 \%$ in the long run. The finding contradicts the conventional views that trade openness leads to faster growth of imports than exports and its serious implication on balance of trade and economic growth. In addition, the finding suggests that trade openness promotes efficient resource allocation and market expansion so per unit cost of output falls to make the economy more competitive. Besides, foreign exchange from exports and cross-border import tariffs and other benefits emanating from trade openness exceeds its related problems in the economy. The finding is consistent with the studies conducted by Mwaba [47], Yanikkaya [48], Shaheen et al. [49], Asiedu [50], and Biwott et al. [51], but it opposes the outcomes of Simorangkir [52], and Karras [53].

The estimated long run results also depicted a positive and statistically significant coefficient of foreign direct investment at $1 \%$ level of significance. With a coefficient of 0.000254 , it means that economic growth is less elastic to international capital inflows. The positive coefficient is not surprising because of the 'technological diffusion' emanating from firms into the economy in the form of spreading foreign capital and technical support to the corporate environment. The technological diffusion is also associated with positive spillover effect in the form of development of sales network and managerial training to local employees and production of higher quality products and competition effect on the domestic firm. Similar results were found by Campos and Kinoshita [54], Hermes and Lensink [55], Almasaied et al. [56], Hetes et al. [57], Tiwari and 
Mutascu [58], El-Wassal [59], Soumia and Abderrezzak [60], and Mbulawa [46].

\subsection{VECM Short-Run Dynamic Results}

The short run dynamics was ascertained through the error correction model. The results for the short run dynamics are displayed in Table 5 .

The error correction term $[\operatorname{ECM}(-1)]$ accounts for how fast or slow the endogenous or dependent variable returns or converges to its long run equilibrium as a result of changes or shocks in the exogenous variables. The coefficient of the error correction term also shows the speed with which any shock to the dependent variable in the model is corrected. From Table 5, the coefficient of the error correction term possesses its expected negative sign and also statistically significant at $1 \%$ level. The negative sign of the error correction term suggests that it is effective for the adjustment process of the system to restore to equilibrium. Specifically put, the adjustment coefficient of -0.333437 is a clear indication that the model is stable. It also means that $33 \%$ of the total disequilibrium in the system is corrected within a year. The low coefficient of the adjustment matrix shows

Table 5. VECM short-run dynamic results.

\begin{tabular}{|c|c|c|c|}
\hline \multicolumn{4}{|c|}{ Dependable Variable: D (lnGDP) } \\
\hline Regressors & Coefficient & Standard Error & t-Statistic \\
\hline $\mathrm{D}(\ln \mathrm{GDP}(-1))$ & 0.398436 & 0.18376 & $2.16823^{* *}$ \\
\hline $\mathrm{D}(\operatorname{lnGDP}(-2))$ & -0.158735 & 0.21500 & -0.73831 \\
\hline $\mathrm{D}(\ln \mathrm{GDP}(-3))$ & -0.154333 & 0.21404 & -0.72106 \\
\hline $\mathrm{D}(\operatorname{lnGDS}(-1))$ & -0.033783 & 0.02805 & -1.20420 \\
\hline $\mathrm{D}(\operatorname{lnGDS}(-2))$ & -0.023433 & 0.02259 & -1.03728 \\
\hline $\mathrm{D}(\operatorname{lnGDS}(-3))$ & -0.015575 & 0.01742 & -0.89405 \\
\hline $\mathrm{D}(\ln \mathrm{CPI}(-1))$ & 0.000280 & 0.06368 & 0.00440 \\
\hline $\mathrm{D}(\ln \mathrm{CPI}(-2))$ & -0.099783 & 0.05248 & $-1.90119^{*}$ \\
\hline $\mathrm{D}(\operatorname{lnCPI}(-3))$ & 0.045192 & 0.04850 & 0.93186 \\
\hline $\mathrm{D}(\ln \mathrm{TO}(-1))$ & -0.018181 & 0.05054 & -0.35976 \\
\hline $\mathrm{D}(\ln \mathrm{TO}(-2))$ & -0.015005 & 0.04163 & -0.36044 \\
\hline $\mathrm{D}(\ln \mathrm{TO}(-3))$ & -0.055284 & 0.04425 & -1.24935 \\
\hline $\mathrm{D}(\mathrm{FDI}(-1))$ & $1.56 \mathrm{E}-05$ & $3.3 \mathrm{E}-05$ & 0.47789 \\
\hline $\mathrm{D}(\mathrm{FDI}(-2))$ & $6.55 \mathrm{E}-05$ & $3.4 \mathrm{E}-05$ & $1.93954^{*}$ \\
\hline $\mathrm{D}(\mathrm{FDI}(-3))$ & $2.49 \mathrm{E}-05$ & $4.0 \mathrm{E}-05$ & 0.62685 \\
\hline $\operatorname{ECM}(-1)$ & -0.333437 & 0.10422 & $-3.19944^{* * *}$ \\
\hline $\mathrm{C}$ & 0.064438 & 0.02949 & $2.18508^{\star *}$ \\
\hline R-squared & 0.605418 & Sum Sq. Residuals & 0.035287 \\
\hline Adj. R-squared & 0.300513 & S.E. Equation & 0.040049 \\
\hline F-statistic & $19.85597^{\star *}$ & Log Likelihood & 83.90484 \\
\hline
\end{tabular}

Note: ${ }^{*}{ }^{* *}$, and ${ }^{* * *}$ denote significance at $10 \%, 5 \%$, and $1 \%$ level respectively. 
how slow the return or convergence to equilibrium will be, hence the Ghanaian economy needs more than a year, specifically, three years to clear any distortion and shock to achieve the restoration of long run equilibrium.

The dependent variable has three lags used as independent variables. The first lag possesses its expected positive sign and it is significant at $5 \%$ significance level pointing to the fact that the current growth rate of GDP is positively affected by its immediate past growth. The second and the third lags have unexpected negative sign, although not significant. This is not consistent with economic theory. The statistical insignificance of the second and third lag coefficients of the dependent variable used as independent implies that current growth in GDP is not respectively affected by its values two and three years ago.

With respect to the short run estimates, the coefficient of savings implies that gross domestic savings have negative but insignificant influence on economic growth in the short run since all the lagged variables are insignificant. The negative and lower value suggest that if everyone tries to save an increasing larger portion of income, it triggers economic down turn since the savers will be poorer instead of becoming richer. This is because the economy will slow down from reduction in demand and due to that the same people will be cyclically unemployed. Therefore, increased savings represent a diminishing circular flow of income. This confirms that the paradox of thrift works for Ghana in the short run.

At the first lag, the coefficient of FDI is positive but statistically insignificant. The coefficient of the FDI at lag two is positive, elastic and statistically significant at $5 \%$. Since FDI measures international capital flow, the high positive and elastic coefficient implies a high degree of international capital flow in Ghana. This is not surprising due to the positive spillover effect of FDI in the form of forward and backward linkages and technical training FDI brings in the hosting economy. This compliments domestic savings to finance economic growth in the model. It also implies that history of FDI two years ago has more than proportionate impact on current growth of the economy.

The coefficients of trade openness at all the lags are negative and statistically insignificant even at $10 \%$ significance level. The results obtained from the study show that three-year old history of trade openness in the economy does not have any significant impact on the current growth of the economy. This means that the immediate past years' imports exceed exports since the past values of trade openness negatively affect economic growth. This also suggests that trade liberalisation in Ghana has a negative influence on the growth of the economy in the short run but not significant.

The coefficient of the CPI at lag two is -0.09978 and statistically significant. This means that current growth rate of GDP is negatively influenced by two-year past value of inflation. Since inflation rate shows how uncertain the investment climate looks to potential investors and general instability the economy is, the negative relationship implies that high previous years inflation rate sends decisive signals to the economy in question that has a two-year-old history of uncertainty and macroeconomic instability. This information has a progressive 
tendency to reduce the volumes of current investment and hence economic growth. Also, the coefficients of CPI at lags one and three have insignificant positive effect on economic growth.

\section{Conclusion and Policy Implications}

This study set out to ascertain the relationship between domestic savings and economic growth in the midst of antecedent variables with yearly data during the period of 1970-2013. Using Johansen cointegration test and vector error correction model, the study found that, in the long-run, consumer price index, trade openness, foreign direct investment, and domestic savings have positive significant impacts on economic growth. With respect to the short-run estimates, the lags in domestic savings have negative but insignificant effects on economic growth. Based on these empirical findings, the ensuing policies are recommended to stakeholders to accelerate savings and stimulate economic growth in Ghana.

It is generally conceived that financial intermediaries are not common in the rural areas in relation to the urban areas due to high cost of operation in these rural areas. In view of this, savings behaviour is not the best one can boast of, and the few individuals who save do so at a huge cost. Savings are characterised by high shoe leather cost as they frequently have to make a number of trips to the banks in the urban centres to effect basic financial transactions. This makes saving unattractive and expensive in the eye of the large rural folks in Ghana. This problem can be eradicated if the government through the central bank plays a regulatory role and ensures that the telecommunication companies such as MTN Ghana, tiGO Ghana, Vodafone, and Airtel Ghana who provide basic financial service to liaise and link up with commercial banks to render this service at reduced cost. This is very common in African countries like Zambia, Kenya, and Congo. Even though, this mobile banking service is provided at the doorstep of customers, nevertheless, they do that at a fee (1\% of every withdrawal 50 Ghana Cedis is paid as charge for that service received). A significant number of people have not embraced this service as a reliable financial service provider due to the fee and the fear of being duped. It is, therefore, recommended that the central bank pays a particular attention to rural savings mobilisation through the regulation of mobile banking by allowing the telecommunication companies to also pay interest to savers on their mobile deposits and establishment of banking financial institutions at least in each district in Ghana. These will not only ease the rural folks from incurring shoe leather cost, but also help them to mobilize funds from the rural level for domestic savings to boost growth.

Finally, another measure to mobilise savings for economic growth is to ensure the sustenance of the political stability the country has experienced. When a country is thrown into political unrest, it does not only affect economic activities of various sectors including the financial sector adversely, political instability also creates fear, panic and uncertainty about the returns on investment and savings of potential investors and savers. Domestically, due to the uncertainty, fear 
and panic surrounding the financial market and the entire business climate, individuals lose confidence and trust in the financial sector. This can negatively affect domestic savings. On external front, such fear, and uncertainty in the financial atmosphere emanating from political upheavals have the effect of diminishing foreign direct investment (FDI). It is, therefore, incumbent on the government of Ghana to uphold, guard and sustain the political stability so jealously since it can create a conducive financial atmosphere necessary to mobilise savings and hence economic growth.

\section{References}

[1] Solow, R.M. (1956) A Contribution to the Theory of Economic Growth. The Quarterly Journal of Economics, 70, 65-94. https://doi.org/10.2307/1884513

[2] Deaton, A. (1995) Growth and Saving: What Do We Know, What Do We Need to Know, and What Might We Learn. World Bank, Policy Research Department, Washington DC.

[3] Harrod, R. (1939) An Essay in Dynamic Theory. Economic Journal, 49, 14-33. https://doi.org/10.2307/2225181

[4] Domar, E.D. (1946) Capital Expansion, Rate of Growth, and Employment. Econometrica, 14, 137-147. https://doi.org/10.2307/1905364

[5] Swan, T.W. (1956) Economic Growth and Capital Accumulation. Economic Record, 32, 334-361. https://doi.org/10.1111/j.1475-4932.1956.tb00434.x

[6] Romer, P. (1986) Increasing Returns and Long-Run Growth. Journal of Political Economy, 94, 1002-1037. https://doi.org/10.1086/261420

[7] Lucas, R.E. (1988) On the Mechanics of Economic Development. Journal of Monetary Economics, 22, 3-42. https://doi.org/10.1016/0304-3932(88)90168-7

[8] Rebelo, S. (1991) Long-Run Policy Analysis and Long-Run Growth. Journal of Political Economy, 99, 500-521. https://doi.org/10.1086/261764

[9] Carroll, C.D. and Weil, D.N. (1994) Saving and Growth: A Reinterpretation. Carnegie-Rochester Conference Series on Public Policy, 40, 133-192. https://doi.org/10.1016/0167-2231(94)90006-X

[10] Jappelli, T. and Pagano, M. (1994) Savings, Growth and Liquidity Constraint. Quarterly Journal of Economics, 109, 83-109. https://doi.org/10.2307/2118429

[11] Sinha, D. and Sinha, T. (1998) Cart before the Horse? The Saving-Growth Nexus in Mexico. Economics Lectures, 6, 43-47. https://doi.org/10.1016/S0165-1765(98)00144-X

[12] Rodrik, D. (2000) Saving Transitions. The World Bank Economic Review, 14, 481507. https://doi.org/10.1093/wber/14.3.481

[13] Agrawal, P. (2000) Savings, Investment and Growth in South Asia. Indira Gandhi Institute of Development Research, Mumbai, India.

[14] Carroll, C.D., Overland, J. and Weil, D.N. (2000) Saving and Growth with Habit Formation. The American Economic Reviews, 90, 341-355.

https://doi.org/10.1257/aer.90.3.341

[15] Anoruo, E. and Ahmad, Y. (2001) Causal Relationship between Domestic Savings and Economic Growth: Evidence from Seven African Countries. African Development Review, 13, 238-249. https://doi.org/10.1111/1467-8268.00038

[16] Verma, R. (2007) Savings, Investment and Growth in India: An Application of the ARDL Bounds Testing Approach. South Asia Economic Journal, 8, 87-98. https://doi.org/10.1177/139156140600800105 
[17] Abu, N. (2010) Saving-Economic Growth Nexus in Nigeria, 1970-2007: Granger Causality and Cointegration Analyses. Review of Economic and Business Studies, 3, 93-104.

[18] Lewis, W.A. (1955) Theory of Economic Growth. Allen and Unwin Ltd., London.

[19] Levine, R. and Renelt, D. (1992) A Sensitivity Analysis of Cross Countries Growth Regression. American Economic Review, 82, 942-963.

[20] Mankiw, N.G., Romer, D. and Weil, D.N. (1992) A Contribution to Empirics of Economic Growth. Quarterly Journal of Economic, 107, 681-712. https://doi.org/10.2307/2118477

[21] Alguacil, M., Cuadros, A. and Orts, V. (2004) Does Saving Really Matter for Growth? Mexico (1970-2000). Journal of International Development, 16, 281-290. https://doi.org/10.1002/jid.1075

[22] Sajid, G.M. and Sarfraz, M. (2008) Savings and Economic Growth in Pakistan: An Issue of Causality. Pakistan Economic and Social Review, 46, 17-36.

[23] Shahbaz, M.Q. and Khan, R.E.A. (2010) Old Wine in New Bottles: Saving-Growth Nexus: Innovative Accounting Technique in Pakistan. Theoretical and Applied Economics, 17, 49-60.

[24] Ogoe, E. (2009) An Econometric Analysis of the Causal Relationship between Gross Domestic Savings and Economic Growth in Ghana (1961-2008). Master's Thesis, Department of Economics, Kwame Nkrumah University of Science and Technology, Kumasi.

[25] Pickson, R.B., Enning, K.D. and Siaw, A. (2017) Savings-Growth Nexus in Ghana: Cointegration and Causal Relationship Analyses. Theoretical Economics Letters, 7, 139-153. https://doi.org/10.4236/tel.2017.72012

[26] Misztal, P. (2011) The Relationship between Savings and Economic Growth in Countries with Different Level of Economic Development. Financial Internet Quarterly, 7, 17-29.

[27] Ijeoma, O., Paramaiah, C. and Moshoeshoe, R.E. (2011) Financial Development, Savings and Economic Growth in Lesotho: Evidence from Trivariate Causality Test. International Journal of Economics and Business Studies, 1, 41-55.

[28] Sothan, S. (2014) Causal Relationship between Domestic Saving and Economic Growth: Evidence from Cambodia. International Journal of Economics and Finance, 6, 213. https://doi.org/10.5539/ijef.v6n9p213

[29] El-Seoud, M.S. (2014) Testing the Relationship between Private Savings and Economic Growth: Case of Bahrain. Global Journal of Commerce and Management Perspective, 1, 38-44.

[30] Chaturvedi, V., Kumar, B. and Dholakia, R.H. (2009) Inter-Relationship between Economic Growth, Savings and Inflation in Asia. Journal of International Economic Studies, 23, 1-22.

[31] Mehrara, M. and Musai, M. (2013) The Relationship between Saving and GDP in Iran Based on ARDL Bounds Testing Approach. International Journal of Applied Economic Studies, 1, 1-6.

[32] Mehta, S.N. and Rami, G.D. (2014) Causal Relationship between Savings and Economic Growth in India. Multi Disciplinary Edu Global Quest, 3, 168- 178.

[33] Najarzadeh, R., Reed, M. and Tasan, M. (2014) Relationship between Savings and Economic Growth: The Case for Iran. Journal of International Business and Economics, 2, 107-124. https://doi.org/10.15640/jibe.v2n4a7

[34] Er, P.H., Tugcu, C.T. and Coban, O. (2014) Investigating the Link between Savings, Inflation and Economic Growth: An ARDL Analysis for the Case of Turkey. Journal of Economics, Finance and Accounting, 1, 81-90. 
[35] Jagadeesh, D. (2015) The Impact of Savings in Economic Growth: An Empirical Study Based on Botswana. International Journal of Research in Business Studies and Management, 2, 10-21.

[36] World Bank (2013) World Economic Development Indicators: Ghana Country Data. http://data.worldbank.org/country/ghana

[37] Onwumere, J.U.J. (2005) Business and Economic Research Methods, Don-Vinto Ltd, Lagos, 272 p.

[38] Aghion, P., Comin, D. and Howitt, P. (2006) When Does Domestic Saving Matter for Economic Growth? National Bureau of Economic Research, Cambridge, MA.

[39] Mundell, R.A. (1965) Growth, Stability and Inflationary Finance. The Journal of Political Economy, 73, 97-109. https://doi.org/10.1086/258999

[40] Capolupo, R. and Celi, G. (2008) Openness and Economic Growth: A Comparative Study of Alternative Trading Regimes. Économie Internationale, 4, 5-35.

[41] Xu, G. and Wang, R. (2007) The Effect of Foreign Direct Investment on Domestic Capital Formation, Trade and Economic Growth in a Transition Economy. Evidence from China. Global Economy Journal, 7, 1-21.

https://doi.org/10.2202/1524-5861.1198

[42] Gursoy, F., Sekreter, A. and Kalyoncu, H. (2013) FDI and Economic Growth Relationship Based on Cross-Country Comparison. International Journal of Economics and Financial Issues, 3, 519-524.

[43] Tang, C.F. and Tan, B.W. (2014) A Revalidation of the Savings-Growth Nexus in Pakistan. Economic Modelling, 36, 370-377. https://doi.org/10.1016/j.econmod.2013.10.012

[44] Nwanne, T.F.I. (2014) Implication of Savings and Investment on Economic Growth in Nigeria. International Journal of Small Business and Entrepreneurship Research, 2, 74-86.

[45] Oleka, C.D., Eyisi, A.S. and Mgbodile, C.C.I. (2014) Empirical Analysis of the Relationship between Foreign Exchange Rate and Economic Growth in a Developing Economy: Nigerian Experience. World Journal of Management and Behavioral Studies, 2, 28-36.

[46] Mbulawa, S. (2015) Effect of Macroeconomic Variables on Economic Growth in Botswana. Journal of Economics and Sustainable Development, 6, 68-77.

[47] Mwaba, A. (2000) Trade Liberalization and Growth: Policy Options for African Countries in a Global Economy. African Development Bank, Economic Research Paper No. 60, Abidjan.

[48] Yanikkaya, H. (2003) Trade Openness and Economic Growth: A Cross-Country Empirical Investigation. Journal of Development Economics, 72, 57-89. https://doi.org/10.1016/S0304-3878(03)00068-3

[49] Shaheen, S., Ali, M.M., Kauser, A. and Ahmed, F.B. (2013) Impact of Trade Liberalization on Economic Growth in Pakistan. Interdisciplinary Journal of Contemporary Research in Business, 5, 228-240.

[50] Asiedu, M.K. (2013) Trade Liberalization and Growth: The Ghanaian Experience. Journal of Economics and Sustainable Development, 4, 125-135.

[51] Biwott, P.K., Moyi, E.D. and Khainga, D. (2013) Trade Liberalization and Economic Growth: The Role of Regulatory Policies. Journal of World Economic Research, 2, 45-57. https://doi.org/10.11648/j.jwer.20130203.13

[52] Simorangkir, I. (2006) The Openness and Its Impact to Indonesian Economy: A SVAR Approach. Center for Central Banking Education and Studies, Bank Indonesia, Jakarta. 
[53] Karras, G. (2006) Trade Openness, Economic Size and Macroeconomic Volatility: Theory and Empirical Evidence. Journal of Economic Integration, 21, 254-272. https://doi.org/10.11130/jei.2006.21.2.254

[54] Campos, N.F. and Kinoshita, Y. (2002) Foreign Direct Investment as Technology Transferred: Some Panel Evidence from the Transition Economies, William Davidson Institute Working Paper No. 438, Ann Arbor, MI.

[55] Hermes, N. and Lensink, R. (2003) Foreign Direct Investment, Financial Development and Economic Growth. The Journal of Development Studies, 40, 142-163. https://doi.org/10.1080/00220380412331293707

[56] Almasaied, S.W., Baharumshah, A.Z. and Rashid, S. (2008) The Impact of Domestic and Foreign Direct Investments on Economic Growth: Evidence from ASEAN Countries. Pertanika Journal of Social Sciences and Humanities, 16: 239-255.

[57] Hetes, R., Moldovan, N. and Miru, O. (2009.) Foreign Direct Investments and Economic Growth in Central and Eastern European Countries. Megatrend Review, 6, 239-252.

[58] Tiwari, A.K. and Mutascu, M. (2011) Economic Growth and FDI in Asia: A Panel-Data Approach. Economic Analysis and Policy, 41, 173-187. https://doi.org/10.1016/S0313-5926(11)50018-9

[59] El-Wassal, K.A. (2012) Foreign Direct Investment and Economic Growth in Arab Countries (1970-2008): An Inquiry into Determinants of Growth Benefits. Journal of Economic Development, 37, 79-100.

[60] Soumia, Z. and Abderrezzak, B. (2013) The Determinants of Foreign Direct Investment and Their Impact on Growth: Panel Data Analysis for AMU Countries. International Journal of Innovation and Applied Studies, 2, 300-313.

\section{Submit or recommend next manuscript to SCIRP and we will provide best} service for you:

Accepting pre-submission inquiries through Email, Facebook, LinkedIn, Twitter, etc. A wide selection of journals (inclusive of 9 subjects, more than 200 journals)

Providing 24-hour high-quality service

User-friendly online submission system

Fair and swift peer-review system

Efficient typesetting and proofreading procedure

Display of the result of downloads and visits, as well as the number of cited articles

Maximum dissemination of your research work

Submit your manuscript at: http://papersubmission.scirp.org/

Or contact tel@scirp.org 